\title{
Survival and growth of Acacia mangium Willd. bare-root seedlings after storage and transfer from aeroponic culture to the field
}

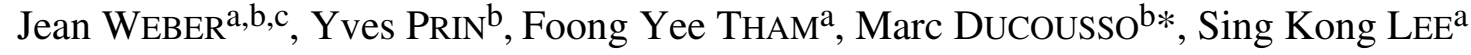 \\ a Nanyang Technology University/National Institute of Education, Natural Science Division, 1 Nanyang Walk, Singapore 637616, Singapore \\ ${ }^{b}$ Laboratoire des Symbioses Tropicales et Méditerranéennes, UMR 113 CIRAD/INRA/Agro-M/UM2/IRD, TA 10/J, \\ 34398 Montpellier Cedex 5, France \\ ${ }^{c}$ UMR INRA-University Henri Poincaré Nancy, Interactions Arbres/Microorganismes, Faculté des Sciences, BP 239, \\ 54506 Vandœuvre-lès-Nancy Cedex, France
}

(Received 30 August 2004; accepted 25 April 2005)

\begin{abstract}
Aeroponic culture has been shown to be a promising nursery technique to raise A. mangium and to improve growth rates as well as the level of controlled infection with rhizobia and mycorrhizal fungi. This work was designed to determine whether aeroponically grown bareroot seedlings can be stored out of aeroponic troughs, and/or planted to the field without acclimatization in Polybags. After field planting, no significant differences in terms of survival and growth rates were expressed between bare-root seedlings that had been stored in plastic bags for six days or directly transferred to the field, or acclimatized in Polybags. Storage in dark conditions for more than four days significantly affected the survival rates of the seedlings. Aeroponic culture appears to be the method of choice to obtain high quality seedlings, which are much easier to plant and transport compared to those obtained under classical nursery techniques using soil or solid substrate.
\end{abstract}

Acacia / aeroponic culture / bare-root / nursery / field planting

Résumé - Survie et croissance de plants en racines nues d'Acacia mangium Willd. après stockage et transfert de culture aéroponique au champ. La culture aéroponique est une technique de pépinière prometteuse pour la production de plants d'Acacia mangium notamment pour l'amélioration de la croissance des plants ainsi que pour le contrôle des infections par les rhizobia et les champignons mycorhiziens. Afin de déterminer si les plants produits en culture aéroponique peuvent être stockés et/ou plantés directement sans période d'acclimatation en Polybags, un dispositif expérimental a été mis en place. Après plantation au champ, aucune différence significative n'a pu être constatée en termes de survie et de croissance des plants stockés dans des sachets plastiques pendant 6 jours ou transférés au champ directement ou après une période d'acclimatation en Polybags. Le stockage à l'obscurité pendant plus de 4 jours réduit significativement la survie des plants. La culture aéroponique semble être une méthode de choix pour la production de plants de qualité facile à transporter et à planter par rapport aux techniques classiques de pépinières utilisant un substrat solide ou du sol.

Acacia / culture aéroponique / racines nues / pépinière / plantation au champ

\section{INTRODUCTION}

Acacia mangium originates from Queensland in Australia, Papua New Guinea, Irian Jaya, the Sula, Ceram and Aru islands [6]. It has been introduced in other parts of Southeast Asia where it is a renowned species for pulpwood plantations due to its fast growth [2]. The ability of A. mangium to thrive well on infertile soils has partially been attributed to its symbiotic association with nitrogen fixing bacteria and mycorrhizal fungi [5]. Aeroponic culture, a soil-less method, has been shown to be a promising way for growing and for controlled inoculation of A. mangium seedlings. Indeed, the growth and the number of nitrogen-fixing nodules obtained in aeroponic culture has been shown to be 2 to 4 times higher than those reached on a solid substratum [8]. Seedlings that had been inoculated with arbuscular mycorrhizal fungi in pots and raised in aeroponics have shown significantly higher rates of mycorrhization and phosphorus content than seedlings grown in soil [7]. Nevertheless, little information is available on growing A. mangium in the field from bare-root seedlings. Bare-root seedlings are known to be easy and quick to plant as well as convenient to transport to distant planting sites. Successful trials and pilot plantings using bare-root $A$. mangium seedlings have been reported in the Philippines, these seedlings having also developed a better root system [10]. However, a direct planting of aeroponically grown seedlings of A. mangium without any acclimatization period in Polybags containing solid substrate has so far not been tested. Due to their fast-growth, lush foliage

\footnotetext{
* Corresponding author: marc.ducousso@cirad.fr
} 
and soft roots A. mangium seedlings grown in aeroponic troughs are particularly sensitive to dehydration. The root system is also particularly well developed reaching up to $1 \mathrm{~m}$ long, leading to entanglement at the time of transplanting. At the present time Acacia mangium seedlings are grown on a solid substratum in locally established nurseries because seedling transport to the field is rather inefficient as a single truck can transport only a few hundred seedlings at one time. Seedling dispatch to the field meets the same problems and represents a main part of the manpower in plantings. Aeroponically-raised bare-root seedlings can be efficiently packed and easily transported in boxes that would allow transport in large number over large distance. The setting up of appropriate transport and storage conditions that do not affect the quality of aeroponically-raised seedlings are a pivotal matter for the development of industrial plantations. In this study we compared the effect of direct planting, pot acclimatization, and storage conditions on the survival rates and early development of $A$. mangium seedlings raised in aeroponic culture.

\section{MATERIALS AND METHODS}

\subsection{Seed germination and the aeroponic system}

Seeds of A. mangium (Seedlot No. 19297, Australian Tree Seed Centre, CSIRO, Australia) were germinated for seven days on moist tissue paper at room temperature. The seedlings were then carefully transferred into sponge plugs, previously soaked in water, and grown for another week in the greenhouse at $30 \pm 2{ }^{\circ} \mathrm{C}$. Fourteen-day-old seedlings were then transferred into an aeroponic trough with their root system suspended in air [7]. Nutrient mist was supplied to the roots for $40 \mathrm{~s}$ at intervals of $30 \mathrm{~s}$. Plants were maintained in the greenhouse under tropical environmental conditions with temperatures ranging from 27 to $32{ }^{\circ} \mathrm{C}$, relative humidity ranging from 80 to $85 \%$ and high illuminance (daylight with a maximum of 800 to $1000 \mu \mathrm{E} \cdot \mathrm{m}^{-2} \cdot \mathrm{s}^{-1}$ ). After 8 weeks, the roots were inoculated with $0.5 \mathrm{~mL}$ per plant of a 4-day-old culture of Bradyrhizobium sp. strain AUST13C [3, 4]. The plants were then grown in the aeroponic troughs for another 5 weeks before field planting.

\subsection{Experimental design}

The experiment involved 180 plants in 6 treatments using 30 plants for each treatment. Plants were randomly assigned to each treatment from a population of 400 aeroponically-grown seedlings. Four of the treatments concerned storage conditions. For these plants, before storage the plants were cut to the height of the last remaining bud at between 20 and $30 \mathrm{~cm}$ on the stem. The roots were cut to a length of $25 \mathrm{~cm}$. The plants were packed in $20 \mathrm{~L}$ transparent plastic bags at a rate of 5 plants per bag, which were inflated with air and sealed. The bags were stored in darkness for 4 and 6 days (4DD, 6DD) or in the shade for 4 and 6 days (4DS, 6DS). The two other treatments consisted of direct planting of seedlings from the aeroponic trough (NSt) and acclimatization of seedlings in $1.5 \mathrm{~L}$ Polybags for 2 weeks before planting (PA). For these treatments, the stalk and the roots were reduced as described above and the Polybags were filled with soil from the planting site. The plants were watered daily with the same nutrient solution as used in aeroponic culture. The roots were cut just before the transfer to the Polybags and the stalks just before the transfer to the field. Within 2 days plants of all treatments were labeled and transplanted into a fully randomized design in the field in 6 rows of 30 plants each with a square spacing of $1 \mathrm{~m}$. The planting site was on reclaimed land, having a moderately deep clay layer and poor drainage. Plant growth rates were calculated from the height measured between the collar and the last living bud before transplanting and at 2 and 7 months after planting out.

\subsection{Statistical analysis}

A single factor analysis of variance (ANOVA) was performed to determine significant difference of plant height and growth between treatments at $P<0.05$. Differences of survival among the different treatments were estimated by the $[\mathrm{Khi}]^{2}$ test at $P<0.05$. These test procedures were carried out with MINITAB software [9].

\section{RESULTS}

\subsection{Transplanting stress and survival after planting}

Transplanting stress was visible after one week. Some plants began to loose leaves and, under sunlight, the grass-green color of the stem turned to a more brownish color. In some cases, the terminal bud died and growth began in the underlying bud. An examination of the transplants revealed that 2 weeks after transplanting, new lateral roots had developed. Two months after transplanting, all the seedlings were growing well without visible symptoms of stress. The healthy appearance of the plants 2 months after transplanting showed that the seedlings were able to overcome the initial transplanting stress. The distribution of surviving plants was uniform over the different treatments $(P<0.05)$. Treatment 6DD significantly affected the survival of the transplanted seedlings (73\% against 93-96\%). No significant difference in mortality was observed for the other treatments (4-7\%).

\subsection{Plant growth after transplanting}

During the first 2 months, growth rates were moderate comparing to those observed for the following 5 months (Fig. 1). Plants of the treatment 6DD were sensitive to transplanting stress as their growth rates were significantly lower than those of the other treatments except for the treatment 4DD. Storage in dark conditions increased the sensitivity to transplanting stress even after only 4 days. Between the 2 nd and the 7 th months after transplanting, no significant differences in growth rates have been measured between the treatments.

\section{DISCUSSION}

In plantations, survival rates are linked to the ability to survive transplanting stress and to out-compete the growth of noxious grasses. Storage in dark conditions slowed down the recovery of growth and increased mortality after planting, thus affecting the plantation success. The comparatively moderate growth rates observed for each treatment after 2 months were probably linked to the fact that the growth recovery was not initiated from the top shoot but from lateral buds that formed a new leader. The growth of topped seedlings has been reported to recover in a short period without adverse effects or subsequent plant deformations $[1,6]$. Fast-growing A. mangium, which develop a soft stalk and lush foliage were reported to be 


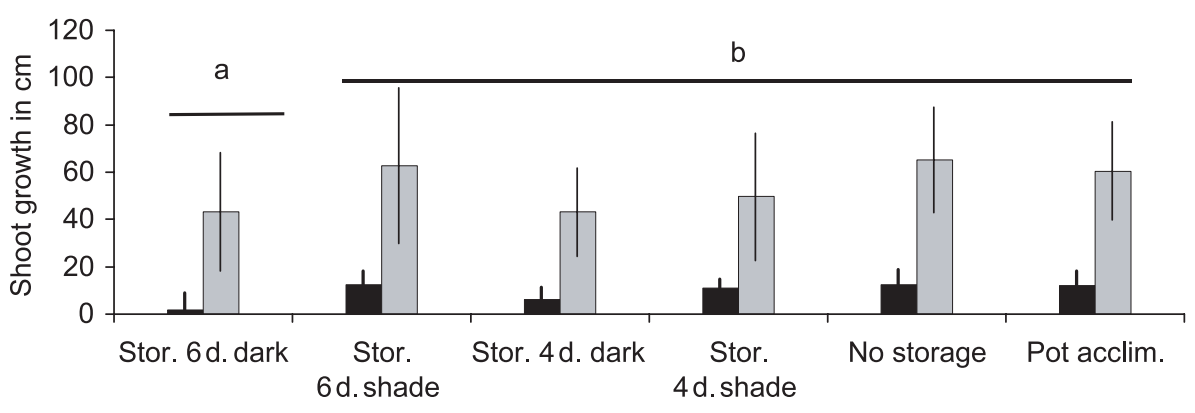

Growth 2 months after transplantation

\section{$\square$ Growth between 2 and 7 months after transplantation}

Figure 1. Acacia mangium shoot growth in $\mathrm{cm}$ (means and standard deviations) 2 months after transplanting and between 2 and 7 months after transplanting according to applied storage conditions. Values under the same bar are not significantly different at $P<0.05$, for both durations.

fragile for handling and sensitive to desiccation. However, it has been shown that they establish well and with a good subsequent growth [6]. This observation was confirmed by our results with $A$. mangium grown in aeroponic culture. The percentage survival rates after transplanting were comparable with the $97 \%$ obtained with the use of containerized seedlings raised under traditional nursery techniques [6]. For fast-growing seedlings a 3 to 4 week hardening procedure has been seen as essential before their transplanting to the field. This procedure consists usually of exposure to full sunlight, and a progressive reduction of nitrogen fertilization and watering with a view to encourage woodiness [6]. The use of bare-root seedlings conditioned in blown-up plastic bags allows the protection of saplings from dehydration and transportation shocks. Field trials in the context of industrial plantings are under progress in collaboration with an industrial pulp company.

Acknowledgements: This work was co-funded by the National Institute of Education of Singapore and the French Ministry of Foreign Affairs. Thanks are also expressed to Olivier Crassard and Patrick Durand respectively for their scientific and administrative assistance.

\section{REFERENCES}

[1] Adjers G., Luukkanen O., Field comparison of A. mangium seedlings with damaged and intact top shoots, in: Ministry of Forestry of Indonesia (Ed.), Trials established in 1986-1987 in the Mechanized Nursery and Plantation Project in South Kalimantan (ATA-
267), Jakarta, Enso Gutzeit Ltd, FINNIDA and University of Helsinki, Finland, 1988.

[2] Cossalter C., Pye-Smith C., Fast-wood Forestry. Myth and realities. Center for International Forestry Research, Jakarta, Indonesia, 2003.

[3] Diouf D., Forestier S., Neyra M., Lesueur D., Optimisation of inoculation of Leucaena leucocephala and Acacia mangium with rhizobium under greenhouse conditions, Ann. For. Sci. 60 (2003) 379-384.

[4] Galiana A., Chaumont J., Diem H.G., Dommergues Y.R., Nitrogen-fixing potential of Acacia mangium and Acacia auriculiformis seedlings inoculated with Bradyrhizobium and Rhizobium spp. Biol. Fertil. Soils 9 (1990) 261-267.

[5] Galiana A., N'Guessan Kanga A., Gnahoua G.M., Balle P., Dupuy B., Domenach A.M., Mallet B., Fixation de l'azote chez Acacia mangium en plantation, Bois For. Trop. 249 (1996) 51-62.

[6] Kamis A., Taylor D., Acacia mangium growing and utilization, MPTS Monograph Series No. 3, Bangkok, Thailand, Winrock International and FAO, 1993.

[7] Martin-Laurent F., Fremont M., Lee S.K., Tham F.Y., Prin Y., Tan T.K., Diem H.G., Effect of inoculation with selected Bradyrhizobium spp. on the survival and growth of Acacia mangium saplings after 20 months in the field, J. Trop. For. Sci. 11 (1999) 470-483.

[8] Martin-Laurent F., Lee S.-K., Tham F.-Y., He J., Diem H.G., Durand P., A new approach to enhance growth and nodulation of Acacia mangium through aeroponic culture, Biol. Fertil. Soil. 5 (1997) 7-12.

[9] Ryan B.F., Joiner B.L., Ryan, T.A., Minitab handbook, Duxburry press, Boston, 1985.

[10] Schroeder P.F., Nursery procedure manual, ASEAN-New Zealand Afforestation project, Manila, Philippines, 1987. 